\title{
A DIVISÃO TRIPARTITE DO SILURIANO DA BACIA DO PARANÁ
}

\author{
PEDRO VICTOR ZALĀN*, SVEN WOLFF*, JOÃO CLÁUDIO DE JESUS CONCEIÇÃO**, \\ INÊS SANTOS VIEIRA*, MARCO ANTONIO MENDONÇA ASTOLFI*, \\ VALÉRIA TIRIBA APPI** e OSMAR ANTÔNIO ZANOTTO**
}

\begin{abstract}
A previously poorly understood, and partly unknown, thick, and widespread Silurian Sequence is recognized in the brazilian portion of the Paraná Basin. Based on electrical log response and lithological differences, this sequence can now be subdivided into three major lithostratigraphic units, from base to top: Rio Ivaí (a new formal unit, here described), Vila Maria, and Furnas Formations. They represent a complete transgression-regression cycle strongly influenced by glaciation. The Rio Ivaí Formation is a predominantly sandy unit, with intercalated diamictites, of continental character at the base becoming marine-influenced toward its upper part. The Vila Maria Formation is represented by intercalations of sandstones and fossiliferous shales, some diamictites, and indicates the peak of the marine transgression. The Furnas Formation is a sandy pile of stacked anastomosing paleo-channels, probably formed as outwash in a periglacial fringe (regressive phase). The only unit surely dated as Early Silurian is the Vila Maria Formation. The Silurian age of the other formations is indicated by stratigraphic relationship. The Rio Ivaí Formation rests unconformably, in some places, over Cambro-Ordovician sedimentary and volcanic rocks; while the Vila Maria grades vertically into the Furnas Formation, that is covered unconformably by the Emsian to Frasnian Ponta Grossa Formation. Known maximum thicknesses of the Silurian Sequence in Brazil are in the order of $500 \mathrm{~m}$, and it thickens towards the southwest into Paraguay, where the correlatable Itacurubi and Caacupé Groups can attain thicknesses in the order of $1,000 \mathrm{~m}$.
\end{abstract}

\begin{abstract}
INTRODUÇÃo A idade da Formação Furnas da Bacia do Paraná sempre foi uma matéria controversa. Trata-se de uma unidade litoestratigráfica afossilífera que, em sua maior parte aflorante, repousa sobre embasamento magmático-metamórfico; e é recoberta na sucessão estratigráfica pela Formação Ponta Grossa, ricamente fossilífera e de idade devoniana (Emsiano-Frasniano) bem estabelecida. Duas hipóteses alternativas sempre existiram: a. o contato entre as formações Furnas e Ponta Grossa seria transicional e a idade da Formação Furnas, conseqüentemente, seria eodevoniana; e b. o contato seria abrupto, representativo de uma discordância, e a idade da Formação Furnas seria, então, siluriana.
\end{abstract}

Trabalhos detalhados de subsuperfície e reconhecimentos de campo realizados recentemente na Petrobrás, integrados com novas descobertas estratigráficas obtidas por diversos autores, favorecem fortemente a segunda hipótese. A descoberta de uma nova unidade estratigráfica sedimentar fossilífera (Formação Vila Maria) de idade eo-siluriana abaixo da Formação Furnas; sua correlação em subsuperfície em poços da Petrobrás e Paulipetro por vastas extensões da bacia; a determinação do caráter transicional do contato Furnas-Vila Maria em quase toda a bacia (com exceção das regiões de borda); a determinação do caráter abrupto do contato Furnas-Ponta Grossa em poços e nos poucos afloramentos onde ele pode ser observado (representando uma provável discordância); a descoberta de uma terceira unidade litoestratigráfica não-aflorante e de grande extensão abaixo da Formação Vila Maria (aqui formalizada como Formação Rio Ivaí); e a correlação dessas três unidades com outras de idade reconhecidamente siluriana em outras bacias permitem concluir pela existência de um significativo pacote de rochas sedimentares silurianas na Bacia do
Paraná, informalmente englobadas aqui sob a denominação Seqüência Siluriana.

Este trabalho apresenta a descrição detalhada das características (geoelétricas, litológicas e paleoambientais) dessas três unidades silurianas em subsuperfície; a definição formal de uma nova unidade litoestratigráfica (Formação Rio Ivaí) com o seu estratotipo; seções de referência para todas essas unidades; suas extensões e espessuras; possíveis correlações com outras unidades silurianas mais bem conhecidas; e inferências paleogeográficas e tectônicas de caráter regional.

\section{ARCABOUÇO ESTRATIGRÁFICO E ORIGEM DA BA-} CIA A estratigrafia da Bacia do Paraná consiste, basicamente, em cinco seqüências deposicionais principais, que variam, em idade, do Siluriano ao Cretáceo. A figura 1 apresenta a coluna cronolitoestratigráfica da bacia e sua correlação com os eventos tectônicos e magmáticos que afetaram a América do Sul durante o Fanerozóico. É importante frisar que o preenchimento sedimentar da bacia é predominantemente siliciclástico, sendo capeado pelo mais volumoso derrame de lavas basálticas sobre crosta continental do planeta. Camadas de calcário, finas e isoladas, ocorrem somente no Permiano Superior, atingindo algum volume representativo na Formação Irati, no terço norte da bacia. Também são conhecidas ocorrências isoladas de evaporitos (anidrita) na Formação Irati. Tudo isso reflete a localização da Placa Sul-Americana (então, parte do Gondwana) em latitudes bem meridionais durante o Paleozóico, ao contrário dos bem conhecidos e significativos depósitos carbonáticos e evaporíticos dos atuais continentes do hemisfério norte, os quais, naquela época, estavam situados em latitudes equatoriais.

\footnotetext{
*-Departamento de Exploração da Petrobrás (Depex). Avenida Chile, 65, 139 andar, CEP 20031, Rio de Janeiro, RJ, Brasil

** Centro de Pesquisas da Petrobrás (Cenpes). Cidade Universitária, Quadra 7, Ilha do Fundão, CEP 21974, Rio de Janeiro, RJ, Brasil
} 


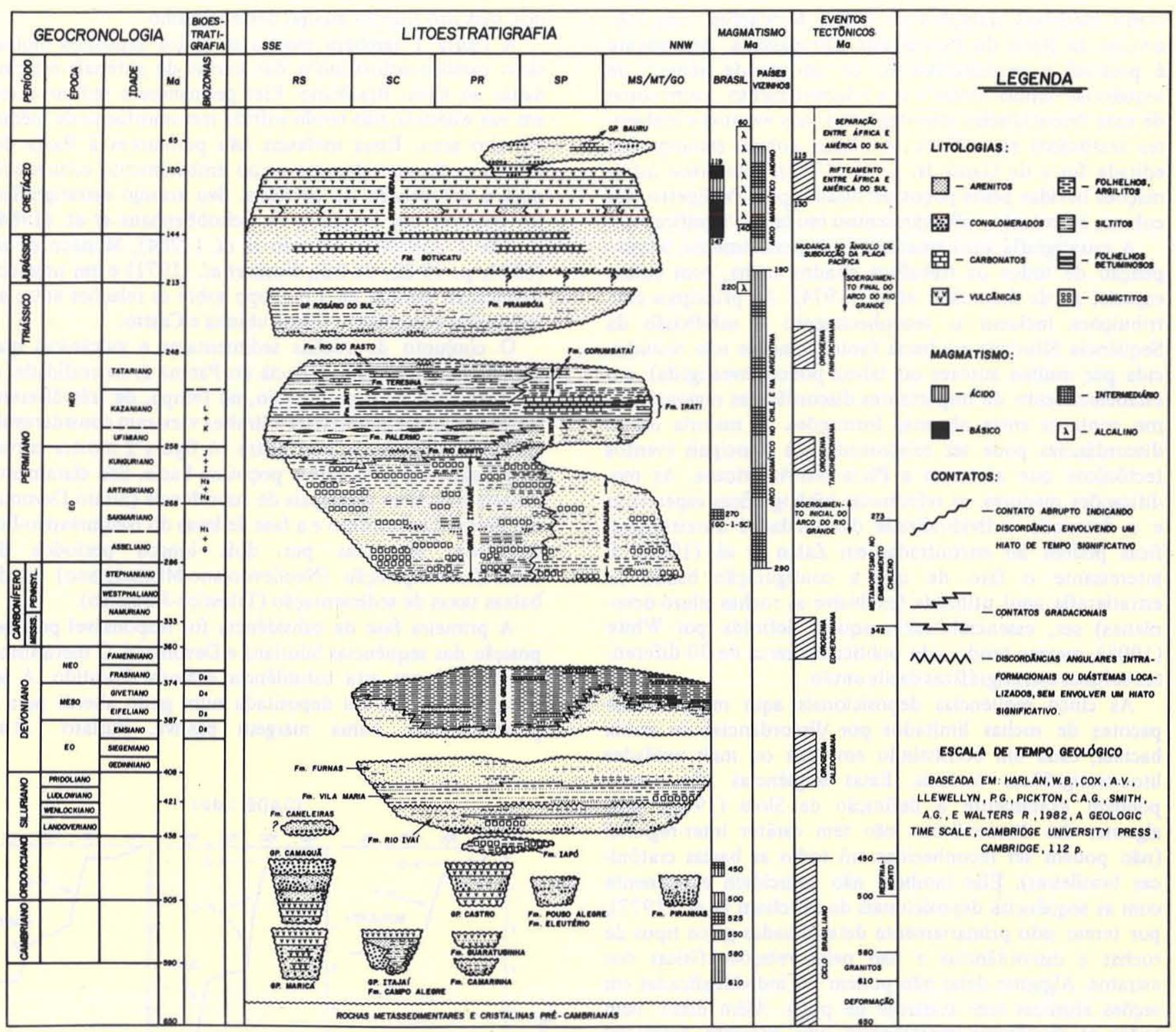

Figura 1 - Coluna cronolitoestratigráfica da Bacia do Paraná mostrando a distribuição temporal e espacial das principais unidades litológicas numa seção hipotética SSE-NNW. Também estão ilustradas as atividades magmáticas e os eventos tectônicos que afetaram a evolução da bacia

A primeira coluna estratigráfica da bacia foi estabelecida por White (1908) e desde então surgiram dezenas de colunas diferentes, bem como nomes para séries, grupos, formações, membros e fácies. Centenas de trabalhos poderiam ser listados aqui, cada um promovendo um pequeno progresso, e freqüentemente confusão, no entendimento da evolução estratigráfica da Bacia do Paraná. O objetivo deste trabalho não é nem apresentar uma evolução do conhecimento por meio da bibliografia existente, nem discutir variações faciológicas em áreas reduzidas. A coluna aqui apresentada é aquela utilizada pelos exploracionistas da Petrobrás na busca de hidrocarbonetos. As divisões litoestratigráficas nela apresentadas são de caráter e utilidade regional, tanto em trabalhos de subsuperfície como de superfície; fornecendo também as mais significativas evidências no que tange à evolução tectono-estratigráfica da bacia.

A primeira síntese geral sobre a geologia da $\mathrm{Bacia}$ do $\mathrm{Pa}$ raná, que aplicou alguns conceitos modernos (análise de bacia, colunas cronoestratigráficas, variações laterais de fácies, inter-relações entre tectônica e sedimentação), foi escrita por Sanford \& Lange (1960). Posteriormente, Northfleet et al. (1969) apresentaram uma excelente revisão da geologia da bacia, baseada em extenso mapeamento de superfície, dados de subsuperfície obtidos pelas dezenas de poços exploratórios e em correlações bioestratigráficas executadas por Daemon \& Quadros (1970). Schneider et al. (1974) refinaram mais a análise estratigráfica e publicaram uma coluna litoestratigráfica atualizada, que se tornou clássica na geologia da Bacia do Paraná, permanecendo a mais completa e utilizada introdução à estratigrafia da bacia.

Soares et al. (1974) tentaram aplicar o conceito de seqüéncias deposicionais síncronas (usando o conceito de Sloss 1963) para as três bacias intracratônicas brasileiras, reconhecendo duas delas na Bacia do Paraná. Foi um trabalho pioneiro e uma boa tentativa, mas, devido à falta de reconhecimento e compreensão da Seqüência Siluriana, assim 
como melhores datações de outras formações, esta subdivisão da Bacia do Paraná está ultrapassada. Atualmente é possível o reconhecimento de um grande número de seqüências deposicionais e seu relacionamento, assim como de suas discordâncias inter-regionais, aos eventos e ambientes tectônicos específicos. A última coluna estratigráfica editada foi a de Gama Jr. et al. (1982), com novas informações obtidas pelos poços perfurados pelo Paulipetro. Tal coluna, entretanto, não apresentou mudanças significativas.

A estratigrafia aqui apresentada é, praticamente, a compilação de todos os trabalhos citados acima, com ênfase especial ao de Schneider et al. (1974). As principais contribuições incluem o reconhecimento e subdivisão da Seqüência Siluriana na bacia (anteriormente não reconhecida por muitos autores ou talvez pouco investigada); e o estabelecimento de importantes discordâncias regionais como contatos entre algumas formações. A maioria dessas discordâncias pode ser relacionada aos principais eventos tectônicos que afetaram a Placa Sul-Americana. As modificações menores, as referências bibliográficas específicas e a descrição individualizada das unidades litoestratigráficas podem ser encontradas em Zalán et al. (1986). É interessante $\mathrm{o}$ fato de que a configuração básica da estratigrafia aqui utilizada (exclusive as rochas siluro-devonianas) ser, essencialmente, aquela definida por White (1908), mesmo tendo sido publicadas cerca de 30 diferentes colunas estratigráficas desde então.

As cinco seqüências deposicionais aqui relatadas são pacotes de rochas limitados por discordâncias de escala bacinal, cada um consistindo em uma ou mais unidades litoestratigráficas formais. Estas seqüências não correspondem exatamente à definição de Sloss (1963), pois algumas das discordâncias não têm caráter inter-regional (não podem ser reconhecidas em todas as bacias cratônicas brasileiras). Elas também não coincidem exatamente com as seqüências deposicionais de Mitchum et al. (1977), por terem sido primariamente determinadas pelos tipos de rochas e discordâncias e não pelas relações físicas dos estratos. Algumas delas não podem ser individualizadas em seções sísmicas sem controle de poço. Além disso, nem todas as seqüências representam uma sucessão previsível de rochas depositadas durante um ciclo global ou regional de mudança relativa do nível do mar. As seqüências aqui descritas correspondem mais a grandes unidades limitadas por discordâncias, ou seja, os sintemas de Chang (1975).

As denominações dessas seqüências deposicionais são informais. Muitas séries e grupos foram criados e formalmente descritos e nominados no passado. Embora isso seja válido num senso litoestratigráfico, na maior parte das vezes, as unidades abrangiam aspectos diferentes (pertenciam a diferentes seqüências e ambientes deposicionais) ou seccionavam ambientes sedimentares similares, de tal maneira que seu uso prático é quase inviável. As seqüências deste trabalho serão nominadas pelo período de tempo no qual a maior parte da sedimentação teve lugar. Desta forma, temos as seqüências Siluriana, Devoniana, Permo-Carbonífera, Triássica e Juro-Cretácea. É preciso que se entenda que essas denominações são informais, baseadas nas datações paleontológicas correntes. A Seqüência Siluriana, por exemplo, iniciou sua sedimentação provavelmente durante o Ordoviciano, concluindo-a no Eodevoniano, mas o grosso da sedimentação ocorreu no Siluriano. No futuro, essas seqüências terão de ser formalizadas em grupos ou supergru- pos, mas isto foge ao escopo deste trabalho.

A figura 1 também mostra os vários depósitos molássicos cambro-ordovicianos das bacias de antepaís relacionadas ao Ciclo Brasiliano. Eles permanecem sedimentares em sua essência, não tendo sofrido metamorfismo de médio ou alto grau. Essas molassas não pertencem à Bacia do Paraná e são consideradas como embasamento econômico para a prospecção de petróleo. Seu arranjo estratigráfico foi baseado nos trabalhos de Schobbenhaus et al. (1984, p. 318 e 338-340), Macedo et al. (1984), Monaco et al. (1974, p. 19-22, 31-32), Fuck et al. (1971) e em uma comunicação pessoal de J.H. Popp sobre as relações entre as formações Camarinha, Guaratubinha e Castro.

$\mathrm{O}$ conjunto de rochas sedimentares e vulcânicas que atualmente compõem a Bacia do Paraná é, na realidade, o produto final da superposição, no tempo, de três diferentes bacias, cujas geometrias e limites variaram consideravelmente de uma bacia para outra. A figura 2 mostra curvas de subsidência para vários poços na bacia. São claramente visíveis três fases principais de subsidência (Siluro-Devoniano, Permo-Carbonífero e a fase de lavas do Neojurássico-Eocretáceo), separadas por dois longos períodos de erosão/não-deposição (Neodevoniano-Mississipiano) ou de baixas taxas de sedimentação (Triássico-Jurássico).

A primeira fase de subsidência foi responsável pela deposição das seqüências Siluriana e Devoniana. O mecanismo responsável por esta subsidência é ainda discutido. A seqüência Siluriana foi depositada num golfo aberto para o proto-Pacífico, numa margem passiva. Fúlfaro et al.

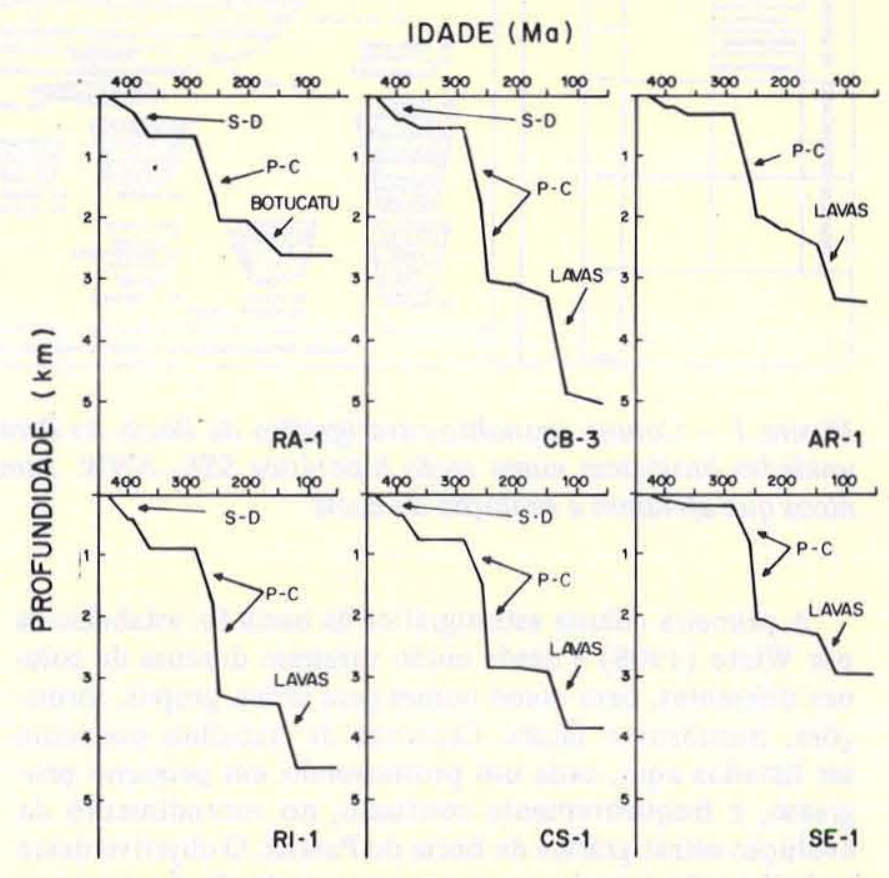

Figura 2 - Acumulação de sedimentos em função do tempo para seis poços na Bacia do Paraná. Os poços RA-1-MT, CB-3-SP, RI-1-PR, CS-1-PR e SE-1-SC estão situados num perfil $N-S$ ao longo da longitude $52^{\circ} \mathrm{W}$, entre as latitudes $19^{\circ} S$ (RA-1-MT) e $270 S$ (SE-1-SC). O poço AR-1-SP está situado no quadrante nordeste da bacia. Não foram efetuadas correções para as seções ausentes devido a discordâncias ou compactação. Estão evidênciadas três fases principais de subsidência da bacia: Siluriano-Devoniano $(S-D)$, Permo-Carnifero $(P-C)$ e durante a erupção das lavas 
(1982) e Petri \& Fúlfaro (1983) chegaram a esboçar esta ligação geográfica para explicar os então pouco conhecidos depósitos silurianos da Bacia do Paraná (Grupo Caacupé e Formação Vila Maria). A discordância caledoniana (Fig. 1) provavelmente assinala a transição da margem passiva para margem compressional; durante a qual o proto-Arco de Assunção se desenvolveu. Fúlfaro et al. (op. cit.) datamo levantamento do Arco de Assunção como sendo do final do Siluriano e início do Devoniano. Este soerguimento inicial reflete provavelmente a resposta flexural da crosta à sobrecarga dos primeiros acavalamentos da margem proto-pacífica. A trangressão devoniana ocupou, praticamente, a mesma área da Seqüência Siluriana, delineando assim a forma da Bacia do Paraná siluro-devoniana. Um soerguimento geral associado à Orogenia Eo-herciniana (Fig. 1) determinou o fim da sedimentação e, provavelmente, o fim da primeira Bacia do Paraná.

A segunda fase de subsidência (Permo-Carbonífero) começou logo que a Bacia do Paraná deixou o Pólo Sul e as geleiras continentais começaram a derreter num ambiente periglacial. É provável que a subsidência inicial da segunda Bacia do Paraná se tenha dado devido à sobrecarga das geleiras continentais, seguida pelo peso dos sedimentos oriundos do ciclo transgressivo-regressivo Permo-Carbonífero. A forma da bacia era então completamente diferente da anterior. $\mathrm{O}$ mar epicontinental e os ambientes litorâneos e continentais associados ocuparam uma área bem mais extensa. A mudança na geometria da bacia e na faciologia de seu preenchimento sedimentar é tão significativa que o conceito de duas Bacias do Paraná (devoniana x gonduânica) tem sido mencionado há algum tempo na literatura geológica (Fúlfaro 1971, Fúlfaro et al. 1982). Um soerguimento generalizado associado à Orogenia Finiherciniana (Fig. 1) cessou a sedimentação, terminando assim a segunda Bacia do Paraná.

A terceira fase de subsidência (Neojurássico-Eocretáceo) coincide com o magmatismo basáltico. $\mathrm{O}$ próprio peso das lavas, provavelmente, causou a subsidência. Esta fase foi a mais importante na evolução da Bacia do Paraná no que tange à estruturação da mesma. Tão intenso foi o tectonismo associado a esta terceira fase que alguns autores chegaram a sugerir uma classificação do tipo rifte para a bacia nesta época (Fúlfaro et al. 1982). O fim da terceira $e$ última Bacia do Paraná coincidiu com o término desse magmatismo (cerca de $120 \mathrm{Ma}$ ), que atingiu não só a bacia mas extensas áreas do Rifte Sul-Atlântico que se encontrava em pleno desenvolvimento. Depósitos cretácicos (grande extensão e pequenas espessuras) e terciários (pequenas extensão e espessura) na metade norte da bacia não são suficientes para caracterizar qualquer outra fase importante de subsidência da bacia comparável às outras três.

Uma questão muito importante concernente à geologia da Bacia do Paraná permanece ainda carente de uma resposta mais concludente. Qual foi a origem da bacia? Levando-se em conta os dados geológicos atuais pode-se dizer que não há qualquer evidência de um rifte central precursor, sob a bacia (o modelo de Steer's head ou Texas Longhorn), como ocorre em outras bacias cratônicas interiores similares. Os depósitos molássicos cambro-ordovicianos são, algumas vezes, invocados como representativos do rifte inicial (Cordani et al. 1984). Alguns deles estão presentemente, preservados em grábens, mas não foram neles formados. O vulcanismo associado a estas rochas está relacionado a ambientes compressionais (andesitos, riólitos) e elas se originaram como depósitos associados à erosão das camadas empilhadas pelos empurrões típicos da Orogenia Brasiliana. Além disso, sua distribuição e espessuras são muito pequenas para a imensa depressão inicial esperada, sem contar a grande diferença temporal entre o início de sua deposição (600 Ma) (início de uma suposta fase rifte) e a dos primeiros sedimentos da Bacia do Paraná (cerca de $440 \mathrm{Ma}$ ) (início de uma suposta fase de subsidência termal). Sendo assim, esta hipótese não será considerada no momento.

Os cálculos de afinamento crustal sob a bacia fornecem valores da ordem de $20 \%$, obtidos pela análise de mapas de isópacas (G.D. Karner, comunicação pessoal) e confirmados por modelamento gravimétrico num perfil NE-SW, na parte nordeste da bacia (Zalán et al. 1986). Durante qual fase teria a bacia experimentado este afinamento crustal? Sendo este fenômeno cumulativo, ter-se-ia distribuído pelas diversas fases de subsidência da bacia? Esta resposta acha-se ainda no campo das especulações.

Deve existir uma relação mais íntima entre o Ciclo Orogênico Brasiliano (700-450 Ma) e a origem da Bacia do Paraná (440-120 Ma), já que o início da primeira fase de subsidência se deu logo após o término da orogenia. 0 Ciclo Brasiliano foi um evento tectônico da natureza compressional, muito intenso e longevo. Vários crátons isolados foram unidos por uma série de eventos colisionais que deformaram e metamorfosearam os cinturões de dobramentos interpostos, originando um significativo magmatismo e remobilizando, isotopicamente, vastas áreas da América do Sul e da África. Após a intensa deformação e granitogênese que ocorreu, aproximadamente entre 700-580 Ma, a litosfera deve ter sido espessada pelo empilhamento advindo dos empurrões, o que, provavelmente, ocasionou um considerável aumento no gradiente geotérmico, decorrente do espessamento de camadas de rochas supracrustais enriquecidas em radioisótopos. 0 resfriamento deste ciclo parece ter ocorrido entre 500-450 Ma (U.G. Cordani, comunicação pessoal), podendo representar um provável mecanismo da subsidência que criou a depressão inicial da Bacia do Paraná, pois os primeiros sedimentos da mesma foram depositados logo após este intervalo de tempo (em torno de $440 \mathrm{Ma}$ ). Uma vez iniciada a sedimentação, o peso dos sedimentos aliado ao resfriamento induziu a subsidência que acolheu as seqüências siluriana e devoniana.

Os primeiros sedimentos da Bacia do Paraná pertencem à Seqüência Siluriana.

SEQÜENCIA SILURIANA Na Bacia do Paraná, as rochas de idade siluriana eram conhecidas somente no seu flanco ocidental, como os grupos Caacupé e Itacurubi (fossilífero) no Paraguai. Na porção brasileira da bacia, a mais antiga seqüência fossilífera conhecida era a Devoniana. As rochas abaixo dela são representadas pela Formação Furnas, caracterizada por um arenito branco, afossilífero, cujo contato com as rochas eodevonianas acima era supostamente de natureza gradacional, sendo, por isso, estimada uma idade neodevoniana para ela. As rochas silurianas são reconhecidas nas outras duas bacias intracratônicas brasileiras e, assim como no Paraguai, elas representam um ciclo completo de transgressão e regressão.

As rochas silurianas, no Paraguai, atingem espessuras de mais de $1.000 \mathrm{~m}$ em seu cinturão de afloramento, no flanco oriental do Arco de Assunção. Litoestratigrafica- 
mente, são divididas em dois grupos (Spinzi 1982, Clérici et al. 1986). O Grupo Caacupé (inferior) é predominantemente arenoso e afossilífero, sendo constituído pelo Conglomerado Paraguari, Arenito Cerro Jhú (ou Piribebuy, arenitos de caráter arcosiano), e Arenito Tobati (arenitos sacaroidais com raras intercalações de folhelhos). Sugere-se aqui um ambiente continental para a deposição deste grupo. 0 Grupo Itacurubi (superior) se destaca do anterior pela presença abundante de fósseis, que determinam tanto a idade siluriana como o ambiente marinho de deposição. Constitui-se, também, de três subdivisões: o Arenito Eusébio Ayala (arenitos finos laminados e siltitos, com colorações indicativas de oxidação), Folhelho Vargas Peña (folhelhos cinzentos, quando não alterados) e Arenito Cariy (arenitos finos a grossos, argilosos, amarelados). O Folhelho Vargas Peña é rico em trilobitas, cefalópodos, pelecípodas, braquiópodas e graptolitos, os quais indicam uma idade llandoveriana. Esta unidade é equivalente à Formação Pitinga do Grupo Trombetas na Bacia do Amazonas e à Formação Tiangá do Grupo Serra Grande na Bacia do Parnaíba (Caputo 1984), representando juntas o clímax da transgressão siluriana.

Faria (1982) descreveu uma nova unidade litoestratigráfica subjacente à Formação Furnas, no extremo norte da Bacia do Paraná, dando-lhe o nome de Formação Vila Maria. Esta Formação apresenta rochas contendo muitos traços-fósseis e fósseis. Uma idade siluriana foi aventada por ele, tendo sido confirmada por Gray et al. (1985) com a utilização de microfósseis.

As correlações por perfis elétricos efetuadas pelos presentes autores estendem esta unidade pela maior parte da Bacia do Paraná e permitem correlacioná-la com o Folhelho Vargas Peña do Grupo Itacurubi. Elas também indicam a presença de uma importante unidade litoestratigráfica subjacente à Formação Vila Maria, a qual não aflora na porção brasileira da bacia. Esta unidade será aqui formalizada com o nome de Formação Rio Ivaí.

As datações paleontológicas da Formação Vila Maria, as correlações de perfis elétricos das Formações Furnas, Vila Maria e Rio Ivaí por meio de 50 poços e dentro da seção paraguaia, além de suas relações de contato, permitiram o reconhecimento de uma espessa, vasta e importante seqüência do Siluriano na porção brasileira da Bacia do Paraná (Fig. 3). Tal volume de rochas silurianas não era anteriormente conhecido e seu reconhecimento tem implicações importantes no que concerne aos aspectos evolutivos da bacia, assim como de seu potencial de hidrocarbonetos.

\section{Formação Rio Ivaí (Definição de uma nova Unidade}

Formal) A Formação Rio Ivaí é uma nova unidade litoestratigráfica, proposta para representar a seção predominantemente arenosa que ocorre abaixo da Formação Vila Maria e acima do embasamento, na parte brasileira da Bacia do Paraná. O embasamento é aqui definido como sendo todas as rochas ígneas ou metamórficas formadas durante ou antes do Ciclo Orogênico Brasiliano (700-450 $\mathrm{Ma}$ ), assim como todas as rochas sedimentares do Cambro-Ordoviciano tidas como molassas derivadas desse ciclo.

A seção-tipo da Formação Rio Ivaí é o intervalo 5.045-5.286 m (-4.739-4.980 m, em relação ao nível do mar) do poço 2-RI-1-PR (Rio Ivaí n.o 1, estratigráfico), do qual veio a denominação da formação. Ressalte-se que o

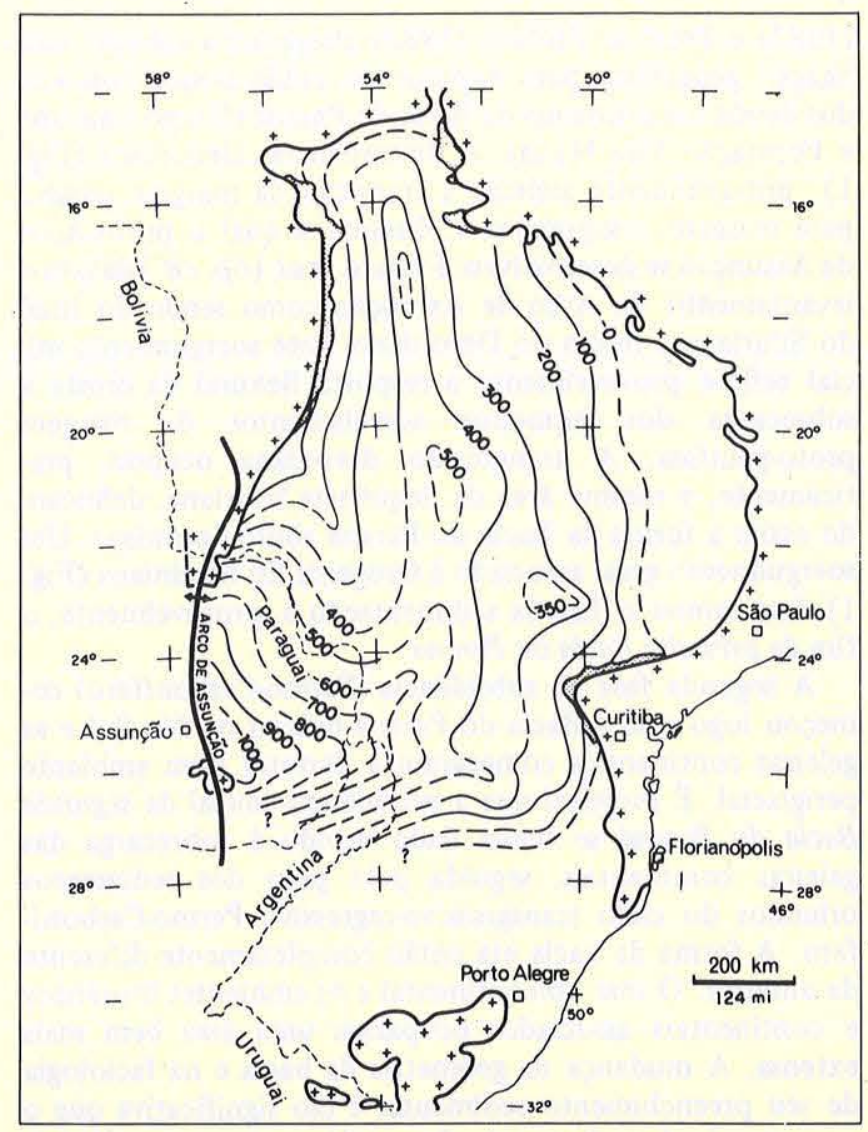

Figura 3 - Mapa de isópacas da Seqüência Siluriana

intervalo 5.222-5.242 m está excluído da seção por representar um diabásio mesozóico. 0 poço foi furado pelo Paulipetro entre 28 de março de 1981 e 16 de abril de 1982, tendo as seguintes coordenadas geográficas: $23^{\circ} 15^{\prime} 52^{\prime \prime}$ sul e $52^{\circ} 27^{\prime} 18^{\prime \prime}$ oeste, estando localizado no município de São Carlos do Ivaí, Estado do Paraná.

A Formação Rio Ivaí, em sua seção-tipo (Fig. 4), tem $221 \mathrm{~m}$ de espessura e consiste em $12 \mathrm{~m}$ de conglomerado basal, seguidos de $82 \mathrm{~m}$ de arenitos (brancos, algumas vezes amarelados ou vermelhos, granulometria média, mal selecionados, algo friáveis) com intercalações finas de folhelho (cinza, também castanho-esverdeado, às vezes preto). Acima, ocorrem $13 \mathrm{~m}$ de diamictito (cinza-claro a esverdeado, duro, clastos centimétricos numa matriz areno-argilosa), coberto por $40 \mathrm{~m}$ de folhelho síltico (verde, cinza a vermelho-tijolo). Este intervalo de folhelhos ś́lticos é um marco litológico e radioativo dentro da Formação Rio Ivaí, sendo chamado, informalmente, de marco síltico-radioativo. A parte superior da formação é composta por $74 \mathrm{~m}$ de arenitos (brancos, algumas vezes amarelados a esverdeados, granulometria média, mal selecionados, friáveis), com finas intercalações de folhelhos (cinzas a verdes). Não se conhece, por enquanto, o conteúdo fossilífero desta formação. Estudos específicos a esse respeito não foram ainda realizados.

A Formação Rio Ivaí, regra geral, é predominantemente arenosa, com poucas intercalações de níveis argilosos. Seu reconhecimento é feito, principalmente, pelas características em perfil, especialmente a curva de raios gama (Figs. 4, 5 e 6). Os baixos valores de radioatividade, potencial espontâneo e taxas de penetração, quando comparados aos altos 


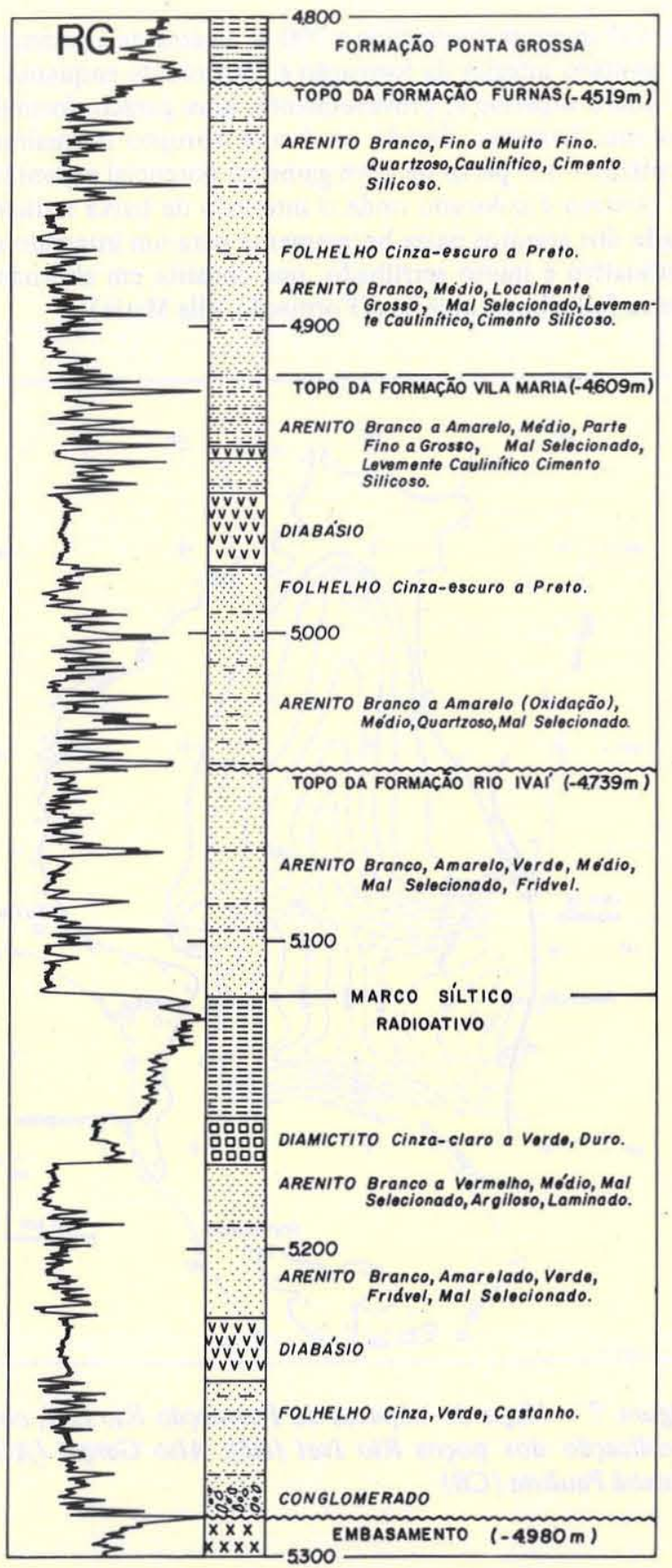

Figura 4 - Seção-tipo da Formação Rio Ivai e seção de referência das formações Furnas e Vila Maria, em subsuperficie. $O$ reconhecimento dessas unidades é baseada, em sua maior parte, em suas respostas em perfis, especialmente aos raios gama. A Formação Furnas apresenta um contato superior abrupto, com valores muito baixos de radioatividade e poucos picos, passando gradualmente para os sedimentos mais argilosos da Formação Vila Maria (caracterizados por uma intensa alternância de estratos radioativos e não-radioativos, cada um com poucos metros de espessura). A Formação Rio Ivai apresenta aos contatos superior e inferior abruptos, baixos valores de radioatividade (muito similares aos valores do Furnas), com raros picos de folhelho. Sua parte central apresenta um marco altamente radioativo, geralmente descrito como um siltito castanho a vermelho (informalmente denominudo marco síltico-radioativo), Poço 2-RI-1-PR (Rio Ivai, no 1)

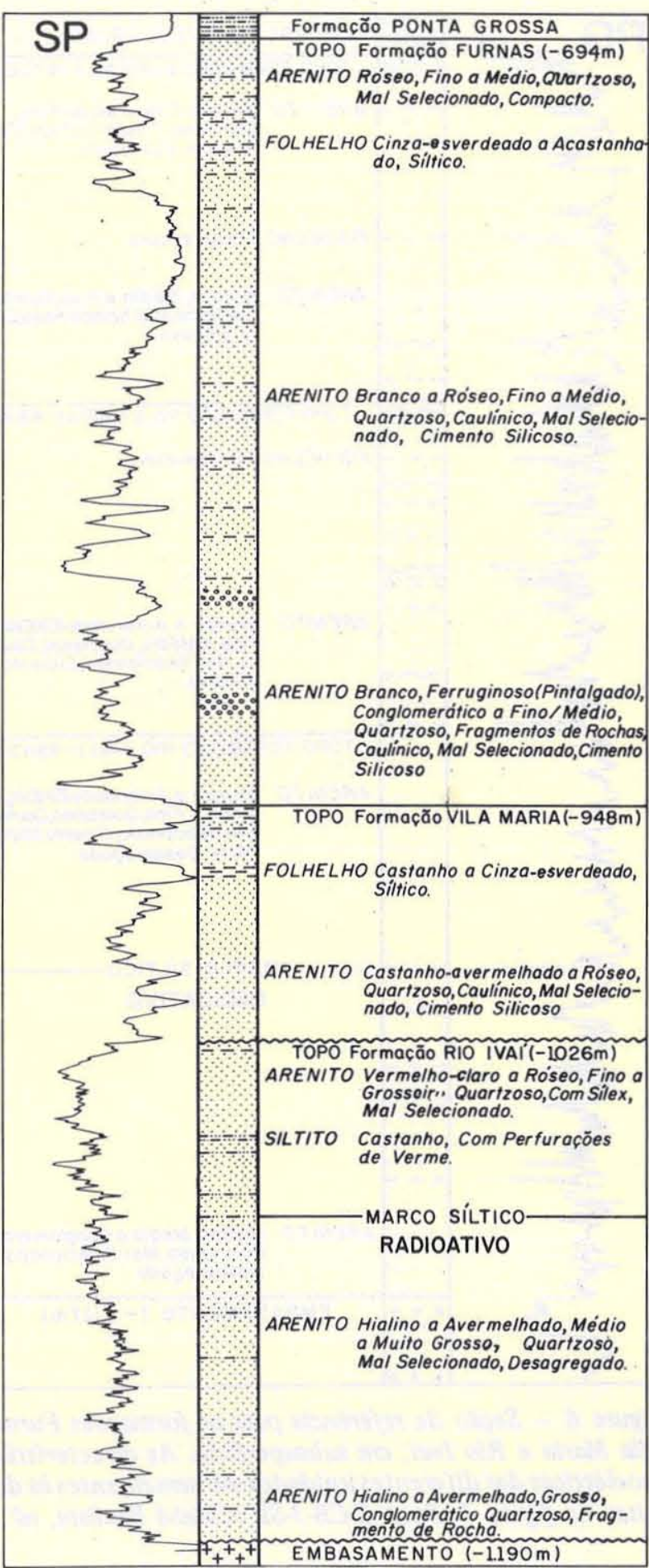

Figura 5 - Seção de referência para as formações Furnas, Vila Maria e Rio Ivai, em subsuperficie. As caracteristicas geolétricas das diferentes unidades são semelhantes às descritas na figura 4. Poço 2-AG-1-MT (Alto Garças, no 1)

valores da Formação Vila Maria, são característicos das formações Rio Ivaí e Furnas: ilustrando muito bem a tripartição da Seqüência Siluriana na Bacia do Paraná. Outras seções de referência para a Formação Rio Ivaí são encontradas nos poços 2-AG-1-MT (1.779-1.944 m (Fig. 5), 3-CB-3-SP (5.322-5.494 m) (Fig. 6), 2-CS-1-PR (4.015-4.196 $\mathrm{m}$, exceto o diabásio situado entre 4.057-4.080 m) e 1-TP-3-SC (3.095-3.211 m). 


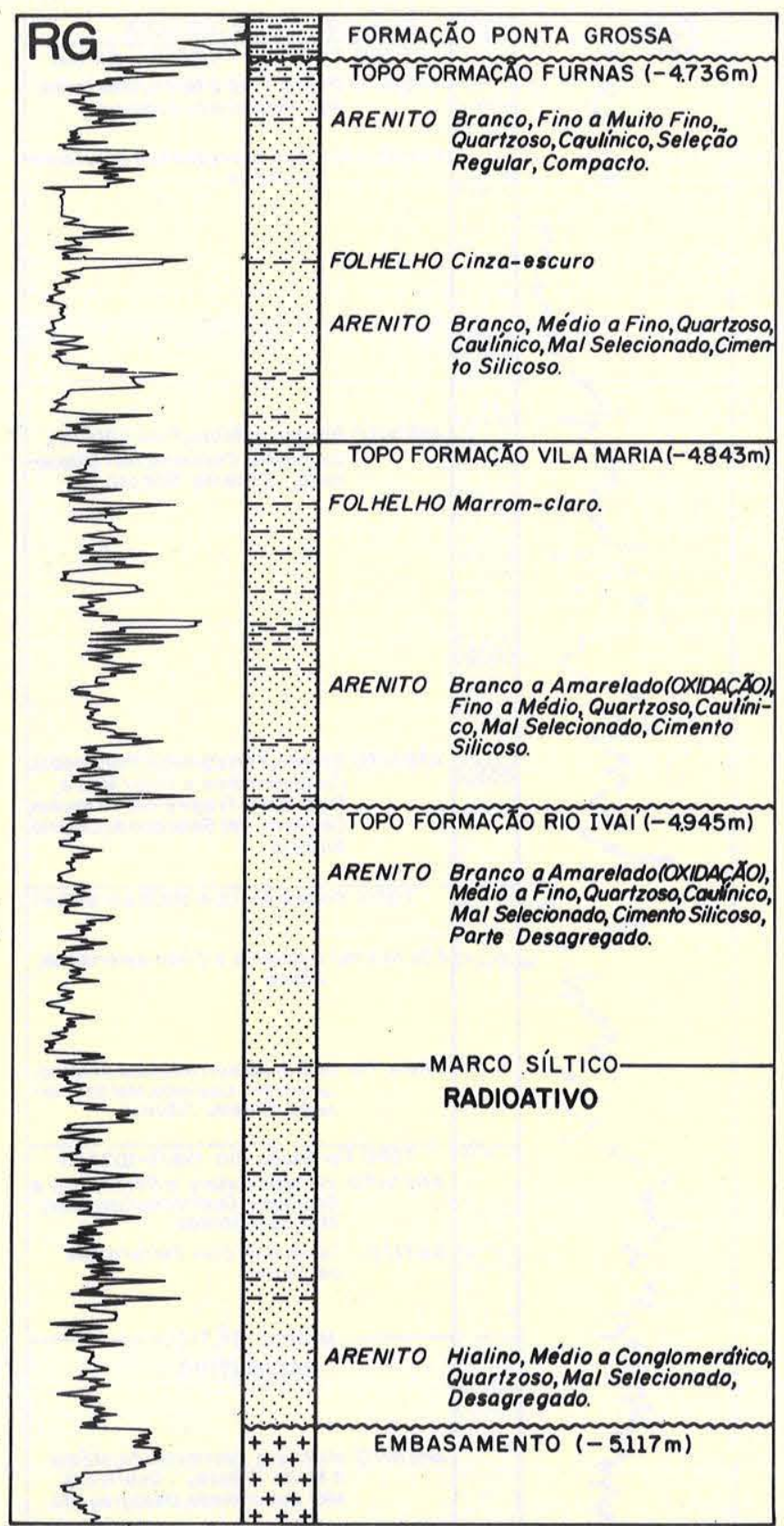

Figura 6 - Seção de referência para as formações Furnas, Vila Maria e Rio Ivai, em subsuperficie. As características geoelétricas das diferentes unidades são semelhantes às descritas na figura 4. Poço 3-CB-3-SP (Cuiabá Paulista, no 3)

A Formação Rio Ivaí tem ampla distribuição na Bacia do Paraná, sendo encontrada em praticamente todos os poços que definem a extensão da Seqüência Siluriana (Fig. 7), salvo em poucos poços próximos às bordas da sequeiência. Até o momento, não há n̉enhuma indicação de afloramento desta unidade no Brasil. Ela é equivalente ao Grupo Caacupé em sua totalidade, juntamente com o Arenito Eusebio Ayala do Grupo Itacurubi, no Paraguai. Também é correlacionável com as formações Nhamundá e Autás-Mirim do Grupo Trombetas (Bacia do Amazonas), e Formação Ipu do Grupo Serra Grande (Bacia do Parnaíba) (Caputo 1984). A espessura máxima encontrada para a Formação Rio Ivaí foi de $221 \mathrm{~m}$ no poço 2-RI-1-PR (Rio Ivaî). No Paraguai, suas unidades correlatas podem atingir mais de $425 \mathrm{~m}$ em subsuperfície e $700 \mathrm{~m}$ na área de afloramento. O contato inferior da formação é discordante enquanto que o limite superior é, provavelmente, uma paraconformidade ou um diastema, devido ao limite abrupto normalmente mostrado nos perfis de raios gama ou potencial espontâneo. O contato é colocado onde o intervalo de baixa radioatividade dos arenitos passa bruscamente para um intervalo mais radioativo e muito serrilhado, que consiste em alternâncias entre folhelhos e arenitos (Formação Vila Maria).

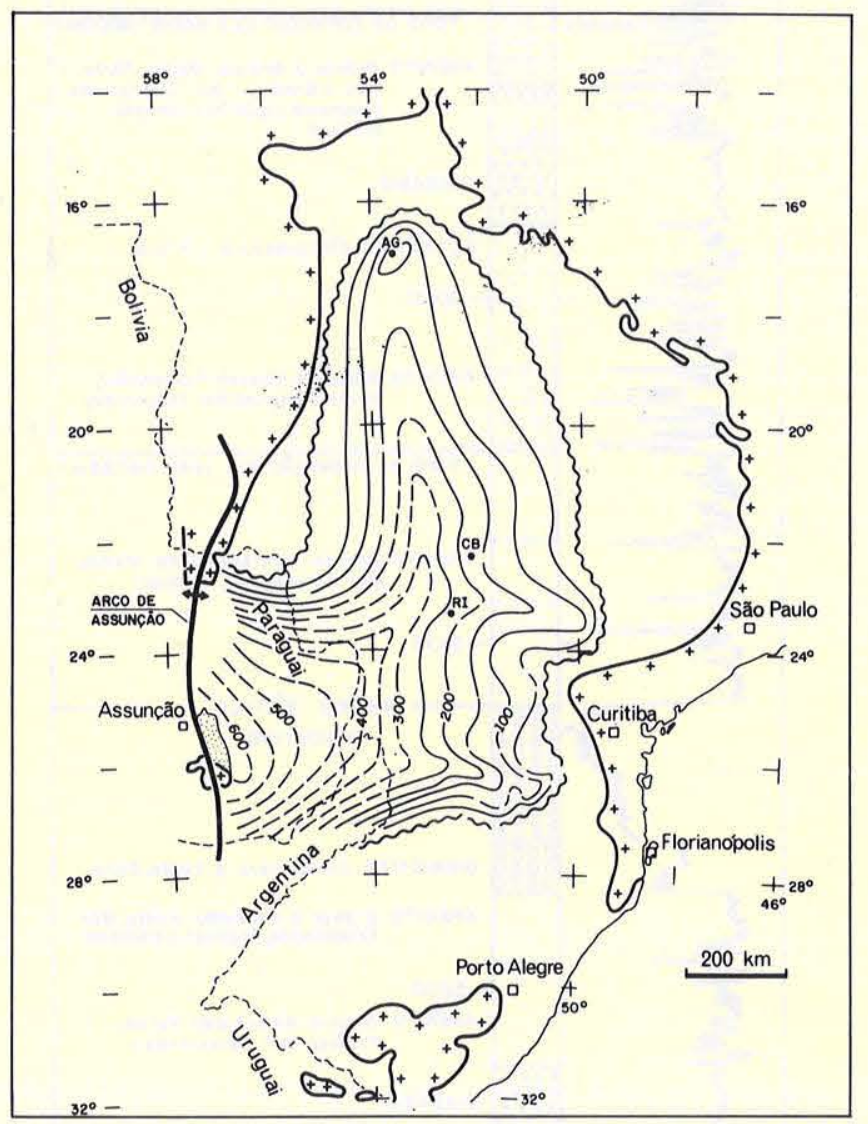

Figura 7 - Mapa de isópacas da Formação Rio Ivaí, com a localização dos poços Rio Ivai (RI), Alto Garças (AG) e Cuiabá Paulista (CB)

Como inferências relativas à idade e gênese não devem fazer parte da definição (Comissão Norte-Americana de Nomenclatura Estratigráfica 1983), elas não serão mencionadas aqui. Estes temas serão discutidos no decorrer do texto.

Formação Vila Maria A Formação Vila Maria foi formalmente descrita por Faria (1982), na faixa de afloramentos do extremo norte da bacia, embora já existissem comunicados pretéritos que se referiam à existência de uma unidade litoestratigráfica abaixo da Formação Furnas (Faria \& Reis Neto 1978, Andrade \& Camarço 1980). Litologicamente, esta unidade é composta de diamictitos polimíticos esverdeados, folhelhos fossilíferos (pretos, cinza-escuros, castanhos e cinza-esverdeados), arenitos (finos a médios, micáceos, feldspáticos, róseos e amarelados, com laminação cruzada e ondulada no topo ) e siltitos vermelhos. As cores vermelha, castanha e roxa (rochas alteradas), assim como verde (rochas frescas), são características. A formação foi 
recentemente datada por Gray et al. (1985) como eo-siluriana. Sua fauna indica condições marinhas, provavelmente um ambiente litorâneo (Gray et al. op. cit.), com alguma influência glacial.

Andrade \& Camarço $(1980,1982)$ correlacionaram esta nova unidade ao intervalo 1.702-1.944 $\mathrm{m}$ do poço 2-AG-1-MT (Alto Garças) (Fig. 5), da Petrobrás, e chamaram o intervalo inteiro de Formação Vila Maria. Os autores deste trabalho concordam parcialmente com esta correlação, principalmente quanto à localização do contato superior. A profundidade de $1.702 \mathrm{~m}$, como mostra o perfil SP, realmente marca uma mudança de uma seção superior predominantemente arenosa (Formação Furnas, cores esbranquiçadas), para uma seqüência inferior de intercalações de arenito (róseo, castanho) e rochas argilosas. Contudo, outra mudança abrupta ocorre a $1.779 \mathrm{~m}$, conforme indicação do perfil SP, taxas de penetração e litologia com a presença de uma seção essencialmente arenosa que se estende até o embasamento, a $1.944 \mathrm{~m}$. Como foi assinalado, anteriormente, estas duas mudanças litológicas podem ser correlacionadas por toda a Bacia do Paraná e subdividem a Seqüência Siluriana em três unidades litológicas distintas. Assim, no poço 2-AG-1-MT, o intervalo 1.779-1.944 m representa a Formação Rio Ivaí, como foi definida neste trabalho. Esta seção foi denominada de Arenitos Pré-Furnas por geólogos de poço da Petrobrás, por terem percebido a presença de uma acentuada mudança litológica. Já a Formação Vila Maria restringe-se ao intervalo $1.702-1.779 \mathrm{~m}$, que corresponde exatamente, em termos litológicos, à seção aflorante definida por Andrade \& Camarço $(1980,1982)$. O intervalo $1.448-1.702 \mathrm{~m}$ corresponde à Formação Furnas clássica. O poço 2-AG-1-MT é um poço chave pois permite a correlação de unidades de superfície e subsuperfície. A espessura máxima da Formação Vila Maria é de $178 \mathrm{~m}$, no poço 2-RP-1-MT (Fig. 8).

O contato entre as formações Vila Maria e Rio Ivaí é geralmente abrupto (Figs. 4, 5 e 6), por isso se acredita que represente uma inconformidade de curta duração de provável origem tectônica (talvez um pulso primário da latente Orogenia Caledoniana). O contato superior com a Formação Furnas é, geralmente, concordante e de natureza transicional. Contudo, em afloramentos do extremo norte da bacia, este contato é marcado por diastemas (Andrade \&. Camarço 1982).

Não se pode desprezar a possibilidade de a Formação Vila Maria ser correlata à Formação Iapó (diamictitos polimíticos), que ocorre restritamente e aflora no eixo do Arco de Ponta Grossa (Fig. 8), conforme foi sugerido por Caputo \& Crowell (1985). As correlações de poços, contudo, indicam que a Formação Iapó (reconhecida em alguns poços da Petrobrás e Paulipetro) poderia ser mais velha que a Formação Rio Ivaí. Desta maneira, ela representaria um vestígio de uma glaciação do Neo-Ashgilliano. A idade eo-siluriana da Formação Vila Maria, assim como a presença de diamictitos na porção média da Formação Rio Ivaí, sugere que a idade da Formação Rio Ivaí poderia ser neo-ordoviciana (Ashgilliano) a eo-siluriana.

Formação Furnas A Formação Furnas é constituída por arenitos brancos, médios a muito grossos, mal selecionados, cauliníticos, quartzosos e freqüentemente conglomeráticos na base; contendo poucas intercalações decimétricas de leitos de caulinita pura. Os arenitos sempre apresentam estratificação cruzada, predominando o tipo fes-

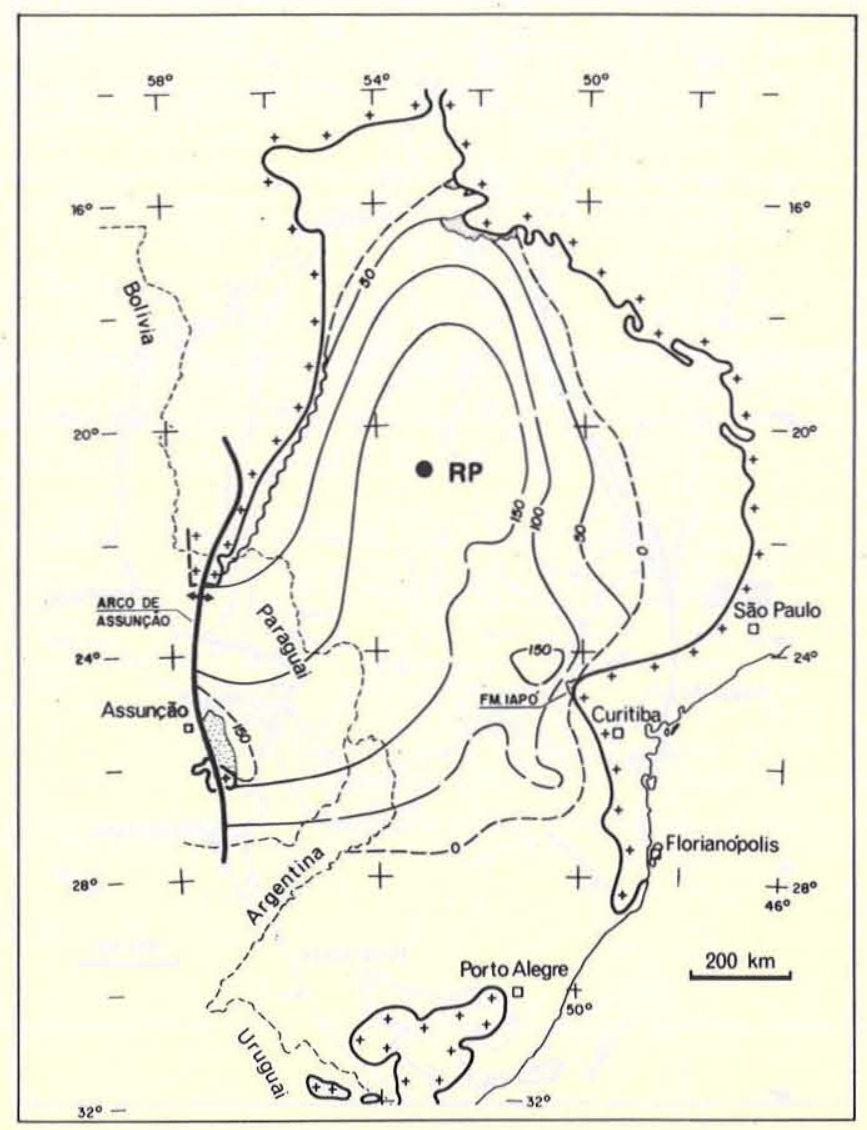

Figura 8 - Mapa de isópacas da Formação Vila Maria

tão e pacotes de estratificação cruzada sigmoidal. As geometrias dos corpos arenosos individualizados, suas estruturas sedimentares e a natureza incisiva de seus contatos indicam, claramente, que a Formação Furnas é um pacote de paleocanais anastomosados, normalmente com poucos metros de profundidade; depositados em um vasto sistema fluvial anastomosado (Schneider et al. 1974). Os arenitos são afossilíferos. Não há qualquer evidência de influência marinha nos afloramentos. Existe uma significativa ausência de fósseis, glauconita e estruturas relacionadas a ondas ou maré. A abundância de caulinita, em vez de outros argilominerais, também é uma evidência de ambientes continentais. Caputo \& Crowell (1985) sugerem que a Formação Furnas ter-se-ia depositado numa franja periglacial, na área de atuação das correntes derivadas do degelo (outwash). No cinturão de afloramentos a nordeste da bacia, podem ser encontradas evidências de retrabalhamento eólico.

A Formação Furnas pode atingir espessuras de mais de $254 \mathrm{~m}$ em subsuperfície (2-AG-1-MT) e de $220 \mathrm{~m}$ na área de afloramento oriental (Fig. 9), onde forma magníficas escarpas. Seu contato inferior, corn a Formação Vila Maria é de natureza gradacional, de acordo com o descrito anteriormente. O contato superior com a Formação Ponta Grossa é discordante. Muitos autores sempre consideraram este contato como gradacional e as razões contra esta idéia serão discutidas adiante. Com base no contato gradacional com a formação sotoposta (datada como eo-siluriana) e no contato discordante com a formação sobrejacente (Emsiano-Frasniano), foi assumida uma idade do Neo-siluriano ao Eodevoniano (Gedinniano, no máximo) para a Formação Furnas. 


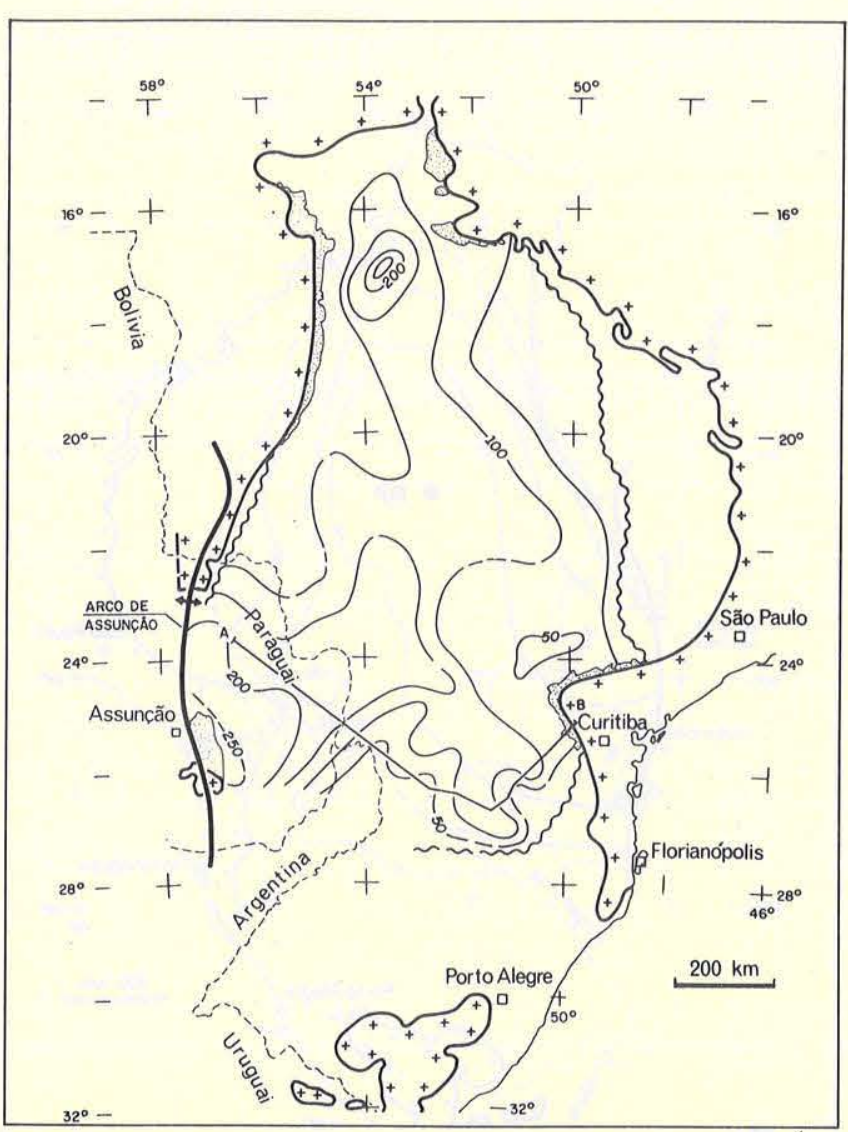

Figura 9 - Mapa de isópacas da Formação Furnas

O Contato Furnas-Ponta Grossa Sempre houve discussões acerca da natureza do contato entre as formações Ponta Grossa e Furnas. Para muitos autores, o nome Ponta Grossa se restringe somente aos folhelhos marinhos (devido a sua definição original) enquanto que Furnas se atém aos arenitos brancos, também de origem "marinha" (interpretação errônea, conforme explanado anteriormente). Desta forma, quando começaram a ser encontrados os arenitos transgressivos, acinzentados, da base da Seqüência Devoniana (tais como os que afloram na região de Jaguariaíva), um caráter transicional foi assumido para o contato entre as formações Ponta Grossa e Furnas. Por outro lado, existe um afloramento importante, onde este contato decisivo pode ser claramente observado (rodovia Castro-Tibagi, próximo à ponte sobre o Rio Tibagi, no Paraná). Ali, folhelhos marinhos repousam, em contato abrupto e claro, sobre arenitos fluviais. Em perfis elétricos este contato é geralmente abrupto também, exceto nas seções onde os arenitos basais transgressivos estão presentes. Nestes casos, testemunhos de arenitos dispostos tanto acima quanto abaixo da discordância revelam diferenças acentuadas na textura, estruturas sedimentares e fácies sedimentares. Em campo, situação semelhante pode ser observada na Chapada dos Guimarães em Mato Grosso. Nas partes mais profundas da bacia, onde a Formação Furnas pode ser de origem marinha, arenitos marinhos se jazem sob arenitos marinhos da Formação Ponta Grossa. Nestas circunstâncias, diferenças agudas na textura dos arenitos indicarão a discordância. Sugere-se que um hiato de cerca de $10 \mathrm{Ma}$ tenha ocorrido entre as formações Furnas e Ponta Grossa. Já o contato superior da Formação Ponta Grossa é, indubitavelmente, uma dis- cordância abrangendo um período de tempo em torno de 60 a $70 \mathrm{Ma}$.

Era comum unir-se as formações Ponta Grossa e Furnas num único grupo (Grupo Paraná) ou numa única série (Série Paraná ou Camıos Gerais). Em vista dos conhecimentos atuais, este agrupamento não tem mais fundamento e deve ser definitivamente abandonado.

COMENTÁRIOS GERAIS A Seqüência Siluriana aqui descrita representa um completo ciclo transgressivo-regressivo fortemente influenciado por glaciação. A Formação Rio Ivaí inicia-se com um conglomerado basal, sendo seguido por depósitos continentais, provavelmente glaciais, em sua parte intermediária. Durante o Eo-siluriano, a Bacia do Paraná estava próxima ao Pólo Sul. Mais para sua parte superior, a Formação Rio Ivaí teve, provavelmente, influência marinha, em resposta à elevação global do nível do mar resultante da fusão das camadas de gelo, à medida que o continente gonduânico migrava para Leste, deixando o Pólo Sul sobre algum lugar do paleo-Oceano Pacífico (ver o comportamento dos centros de glaciação no Paleozóico em Caputo \& Crowell 1985). Enfim, as geleiras derreteram e o nível do mar subiu. $\mathrm{O}$ pico da transgressão é representado pela Formação Vila Maria enquanto a fase regressiva seria representada pela Formação Furnas.

A Seqüência Siluriana da Bacia do Paraná pode, possivelmente, ser correlacionada ao Grupo Table Mountain, na África do Sul. Deste modo, a Formação Rio Ivaí poderia ser correlata à Formação Península; a Formação Vila Maria às formações Cedarberg e Pakhuis; e a Formação Furnas à Formação Nardouw (estratigrafia da África do Sul segundo Tankard et al. 1982 e Gray et al. 1986).

No que diz respeito à paleogeografia, a Seqüência Siluriana foi depositada, provavelmente, em um golfo completamente aberto para oeste, para uma margem passiva do proto-Pacífico. Este golfo era limitado a norte e a sul pelo Cráton do Guaporé e pelo Escudo do Rio Grande/Uruguai, respectivamente. O Arco de Assunção ainda não existia, então. Esta margem passiva prosseguia para sul, via Argentina (área de Sierras Australes), até a África do Sul. Os dados aqui apresentados não favorecem a hipótese aventada por Fúlfaro et al. (1982) da existência de extensos riftes NW-SE durante o Siluriano na Bacia do Paraná. A ampla distribuição e a faciologia da Seqüência Siluriana aqui descrita não são próprias de depósitos aulacogênicos.

Com referência à tectônica, a principal influência sobre a sedimentação foi exercida por sistemas de falhas com direções noroeste (principal) e nordeste, falhas estas existentes no embasamento e que se reativaram, predominantemente, sob a forma de movimentos verticais de blocos (Fig. 10). A sedimentação foi interrompida por um pulso tectônico andino conhecido como Orogenia Caledoniana (Neo-Siluriano-Eodevoniano; Dalmayrac et al. 1980, in Porsche 1985). Um soerguimento geral nas três bacias cratônicas brasileiras é um indicativo deste pulso no Brasil. Em outras partes da América do Sul, discordâncias, plutões graníticos e metamorfismo atestam a Orogenia Caledoniana. O surgimento do Arco de Assunção como um alto topográfico foi uma das mais importantes conseqüências desta orogenia na Bacia do Paraná.

CONCLUSÕES O reconhecimento de uma vasta e significativa Seqüência Siluriana na Bacia do Paraná traz importantes implicações para a evolução geológica paleo- 

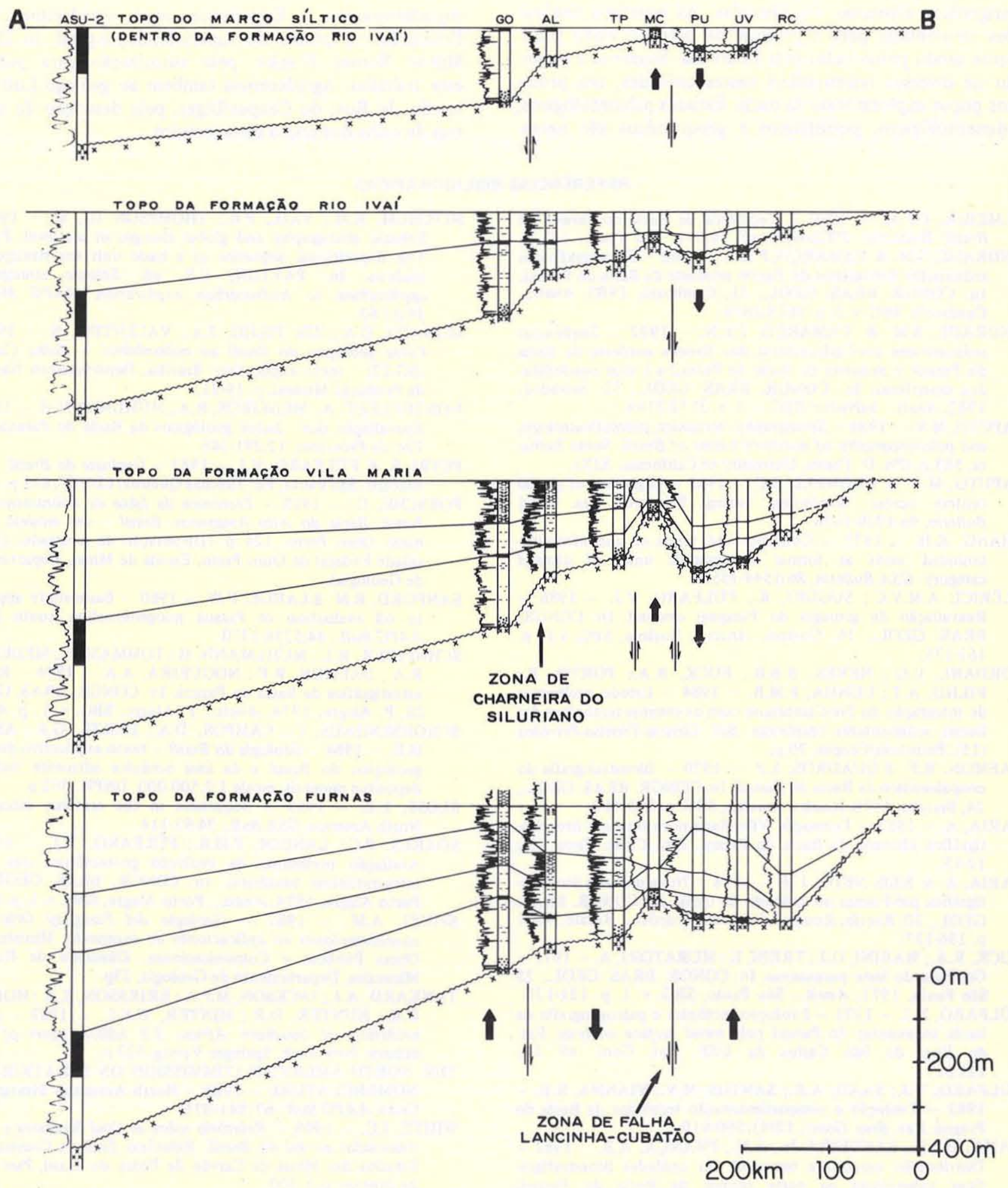

Figura 10 - Seções paleoestruturais ao longo do perfil $A-B$ (localização na figura 9) da Seqüência Siluriana. Os dátuns estão identificados na figura. Observam-se movimentos verticais de blocos e atividade recorrente de certas zonas de falha, especialmente a de Lancinha-Cubatão. Também estão indicadas reversões de movimentos ao longo das falhas. Poços: GO Galvão; AL - Abelardo Luz; TP - Três Pinheiros; MC - Matos Costa; PU - Porto União - UV - União da Vitória; RC - Rio Chapecó 
zóica do continente sul-americano. Inferências acerca de paleoambientes, tectonismo e tectônica de placas puderam ser obtidas pelo estudo detalhado das três unidades litoestratigráficas silurianas reconhecidas. As possíveis implicações econômicas para a geologia de petróleo estão atualmente sendo pesquisadas pela Petrobrás. Sugere-se a obtenção de diversos testemunhos nestas unidades, nos próximos poços exploratórios da bacia. Estudos paleontológicos, sedimentológicos, petrofísicos e geoquímicos são neces- sários para a confirmação das conclusões aqui descritas, e também para uma melhor avaliação do potencial petrolífero das mesmas.

Agradecimentos Expressa-se aqui agradecimentos à Petrobrás, na pessoa do superintendente-geral do Depex Milton Romeu Franke, pela autorização para publicar este trabalho. Agradecemos também ao geólogo Luiz Fernando de Ros, do Cenpes/Diger, pela descrição de amostras de calha dos poços mencionados.

\section{REFERÊNCIAS BIBLIOGRÁFICAS}

ALMEIDA, F.F.M. - 1980 - Tectônica da Bacia do Paraná no Brasil. Relatório IPT/DMGA n? 14.091, São Paulo, 187 p.

ANDRADE, S.M. \& CAMARÇO, P.E.N. - 1980 - Estratigrafia dos sedimentos devonianos do flanco nordeste da Bacia do Paraná. In: CONGR. BRAS. GEOL., 31, Camboriú, 1980. Anais... Camboriú, SBG.v. 5, p. 2828-2836.

ANDRADE, S.M. \& CAMARÇO, P.E.N. - 1982 - Seqüências sedimentares pré-Carboníferas dos flancos nordeste da Bacia do Paraná e sudoeste da Bacia do Parnaíba e suas possibilidades uraníferas. In: CONGR. BRAS. GEOL., 32, Salvador, 1982. Anais... Salvador, SBG. v. 5, p. 2132-2144.

CAPUTO, M.V. - 1984 - Stratigraphy, tectonics, paleoclimatology, and paleogeography of northern basins of Brazil. Santa Barbara, 583 p. (Ph. D. Thesis, University of California, XIX).

CAPUTO, M.V. \& CROWELL, J.C. - 1985 - Migration of glacial centers across Gondwana during Paleozoic Era. GSA Bulletin, 96:1020-1036.

CHANG, K.H. - 1975 - Concepts and terms of unconformitybounded units as formal stratigraphic units of distinct category. GSA Bulletin, 86:1544-1552.

CLERRICI, A.M.V.C.; SUGUIO, K.; FULFARO, V.J. - 1986 Reavaliação da geologia do Paraguai oriental. In: CONGR. BRAS. GEOL., 34, Goiânia. Anais... Goiânia, SBG. v.1, p. 163-175.

CORDANI, U.G.; NEVES, B.B.B.; FUCK, R.A.; PORTO, R.; FILHO, A.T.; CUNHA, F.M.B. - 1984 - Estudo preliminar de integração do Pré-Cambriano com os eventos tectônicos das bacias sedimentares brasileiras. Bol. Ciência-Técnica-Petróleo (15), Petrobrás/Cenpes, 70 p.

DAEMON, R.F. \& QUADROS, L.P. - 1970 - Bioestratigrafia do neopaleozóico da Bacia do Paraná. In: CONGR. BRAS. GEOL., 24, Brasília, 1970. Anais... Brasília, SBG.p. 355-412.

FARIA, A. - 1982 - Formação Vila Maria-nova unidade litoestratigráfica siluriana da Bacia do Paraná. Rev. Ciênc. Terra, (3): $12-15$.

FARIA, A. \& REIS NETO, J.M. - 1978 - Nova unidade litoestratigráfica pré-Furnas no sudoeste de Goiás. In: CONGR. BRAS. GEOL., 30, Recife. Resumo das comunicaf̧ões... Recife, SBG. p. 136-137.

FUCK, R.A.; MARINI, O.J.; TREIN, E.; MURATORI, A. - 1971 Geologia do leste paranaense. In: CONGR. BRAS. GEOL., 25 São Paulo, 1971. Anais... São Paulo, SBG. v. 1, p. 121-130.

FOLFARO, V.J. - 1971 - Evolução tectônica e paleogeografia da bacia sedimentar do Paraná pelo trend surface analysis: Esc. de Eng. de São Carlos da USP, Bol. Geol. n? 14, $111 \mathrm{p}$.

FULFARO, V.J.; SAAD, A.R.; SANTOS, M.V.; VIANNA, R.B. 1982 - Evolução e compartimentação tectônica da Bacia do Paraná.Rev. Bras. Geoc., 12(4):590-610.

GAMA, Jr., E.; BANDEIRA Jr., A.N.; FRANÇA, A.B. - 1982 Distribuição espacial e temporal das unidades litoestratigráficas paleozóicas na parte central da Bacia do Paraná. Rev. Bras. Geoc., 12(4):57 8-589.

GRAY, J.; COLBATH, G.K.; FARIA, A.; BOUCOT, A.J.; ROHR, D.M. - 1985 - Silurian-age fossils from the Paleozoic Paraná Basin, southern Brazil. Geology, 13:521-525.

GRAY, J.; THERON; J.N.; BOUCOT, A.J. - 1986 - Age of the Cedarberg Formation, South Africa and early land plant evolution. Geol. Mag., 123(4):445-454.

MACEDO, M.H.F.; BASEI; M.A.S.; BONHOMME, M.G.; KAWASHITA, K. - 1984 - Dados geocronológicos referentes às rochas metassedimentares do Grupo Itajaí (SC). Rev. Bras. Geoc., 14(1):30-40.
MITCHUM, R.M.; VAIL, P.R.; THOMPSON III, S. - 1977 Seismic stratigraphy and global changes of sea level. Part 2: The depositional sequence as a basic unit for stratigraphic analysis. In: PAYTON, C.E. ed. Seismic stratigraphy applications to hydrocarbon exploration. AAPG Memoir 26:53-62.

MONACO, O.A.; ZIR FILHO, J.A.; VALENTINI, N. - 1974 Carta geológica do Brasil ao milionésimo - Folha Curitiba (SG-22) - texto explicativo: Brasília, Departamento Nacional da Produção Mineral, p. 19-21.

NORTHFLEET, A.; MEDEIROS, R.A.; MÜHLMANN,H. - 1969 Reavaliação dos dados geológicos da Bacia do Paraná. Bol. Téc. da Petrobrás, 12:291-346.

PETRI, S. \& FÚLFARO, V.J. - 1983 - Geologia do Brasil: Fanerozóico. São Paulo, Ed. Thomas Queiroz/EDUSP, 631 p.

PORSCHE, E. - 1985 - Tectónica da faixa de dobramentos do Juruá, Bacia do Alto Amazonas, Brasil - um modelo estrutural. Ouro Preto, 124 p. (Dissertação de mestrado, Universidade Federal de Ouro Preto, Escola de Minas, Departamento de Geologia).

SANFORD, R.M. \& LANGE, F.W. - 1960 - Basin-study approach to oil evaluation of Paraná miogeosyncline, south Brazil. AAPG Bull., 44:1316-1370.

SCHNEIDER, R.L.; MÜHLMANN, H.; TOMMASI, E.; MEDEIROS; R.A.; DAEMON, R.F.; NOGUEIRA, A.A. - 1974 - Revisão estratigráfica da Bacia do Paraná. In: CONGR. BRAS. GEOL., 28, P. Alegre, 1974. Anais... P. Alegre, SBG. v. 1, p. 41-65.

SCHOBBENHAUS, C.; CAMPOS, D.A.; DERZE, G.R.; ASMUS, H.E. - 1984 - Geologia do Brasil - texto explicativo do mapa geológico do Brasil e da área oceânica adjacente incluindo depósitos minerais, escala 1:2.500.000. DNPM. 501 p.

SLOSS, L.L. - 1963 - Sequences in the cratonic interior of North America. GSA Bull., 74:93-114.

SOARES, P.C.; LANDIM, P.M.B.; FÚFARO, V.J. - 1974 Avaliação preliminar da evolução geotectônica das bacias intracratônicas brasileiras. In: CONGR. BRAS. GEOL., 28, Porto Alegre, 1974. Anais... Porto Alegre, SBG. v. 1, p. 61-83.

SPINZI, A.M. - 1982 - Geologia del Paraguay Oriental y consideraciones en aplicaciones de ingenerta. Ministerio de Obras Públicas y Comunicaciones, Dirección de Recursos Minerales, Departamento de Geologia, 23p.

TANKARD, A.J.; JACKSON, M.P.A.; ERIKSSON, K.A.; HOBDAY, D.K.; HUNTER, D.R.; MINTER, W.E.L. - 1982 - Crustal evolution of Southern Africa, 3.8 billion years of Earth history. New York, Springer Verlag. $523 \mathrm{p}$.

THE NORTH AMERICAN COMMISSION ON STRATIGRAPHIC NOMENCLATURE - 1983 - North American Stratigraphic Code.AAPG Bull., 67:841-875.

WHITE, I.C. - 1908 - Relatório sobre as Coal Measures e rochas Associadas ao sul do Brasil. Relatório final da Comissão dos Estudos das Minas de Carvão de Pedra do Brasil, Part 1, Rio de Janeiro.p. 1-300.

ZALẢN, P.V.; CONCEIÇÃO, J.C.J.; WOLFF, S.; ASTOLFI, M.A.M; VIEIRA, I.S.; APPI, V.T.; NETO, E.V.S.; CERQUEIRA, J.R.; ZANOTTO, O.A.; PAUMER, M.L.; MARQUES, A. 1986 - Análise da Bacia do Paraná. Relatório Interno da Petrobrás. Depex/Cenpes n. 103S-5765, Rio de Janeiro, 5 volumes (disponível para consulta).

MANUSCRITO 407

Recebido em 28 de novembro de 1986 Revisão aceita em 08 de junho de 1987 